\title{
The Role Analysis of Waste Bank in Improving the Community's Creative Economy (Study at Ketumbar Pamulang Waste Bank)
}

\author{
Gunartin $^{1}$, Edi Mulyanto ${ }^{2}$, Denok Sunarsi ${ }^{3}$ \\ ${ }^{1,2,3}$ Universitas Pamulang, Tangerang Selatan, Banten, Indonesia \\ lecturer01339@unpam.ac.id,lecturer01755@unpam.ac.id,denoksunarsi@unpam.ac.id
}

\begin{abstract}
The research objective with the title "Analysis of the Role of Waste Banks to Improve the Creative Economy of the Community (Study at the Pamulang Garbage Bank) wants to know and describe the role of waste banks in an effort to improve the community's economy. Research with the object of the Ketumbar waste bank which is located at RW 18 Banda Baru Pamulang, South Tangerang uses a descriptive qualitative approach to explain the existing phenomena or symptoms. The waste bank has a big enough role in dealing with waste problems that have not yet been handled effectively and efficiently. It is hoped that the presence of a waste bank will be able to contribute to reducing the volume of waste as well as improving the creative economy of the community. The research, which uses researchers as its instrument, by conducting data collection techniques through interviews and document studies, determines the coordinator of the Benda Baru waste bank and his three teams as the key informants, which are the primary sources of information. The results show that the role of the waste bank has been able to improve the creative economy of the community but has not been optimal because what has been done is only as a container, the distributor has returned to the stall, has not yet reached the recycling development process so as to produce competitive production if marketed because it is constrained by the craftsmen who have creative power and marketing the creations of used goods craftsmen. This is because people still look down on used goods even though they have been recycled and the government's attention is not yet optimal in opening distribution channels for creative waste products. So the role of the new garbage nk plays a role as an intermediary for the community with used goods collectors stalls.
\end{abstract}

Keywords

the role; waste bank, creative economy

\section{Introduction}

The current global challenges also revise the health system in Indonesia. From this condition, supporting health development is carried out with the support of a good system and human resources equipped with technological support. In the ideal level that outcomes as a desire in the desired health development efforts, so that from this context sustainability will continue to exist. In the formulation made by WHO provides an understanding that the health system is all activities that have the aim to improve, improve or care for health. (Shinta, 2020).

The waste problem has attracted the attention of many parties, including the government and the people of South Tangerang City. The government's and the public's concern for waste problems can be demonstrated by various programs launched by the government to overcome waste problems, such as the waste bank program, go green, the minimum waste program, to imposing taxes on the use of plastic bags in supermarkets. 
However, the volume of waste produced reaches 880 tons per day, which certainly requires special attention to get the right solution. Because if the waste problem is not handled effectively, it will not only spoil the view of city governance, but also have an impact on pollution and environmental damage, such as flooding. For this reason, the government continues to make efforts and synergize with the community together and sustainably to find the right solution to the waste problem. The large volume of waste can cause problems if not handled properly. As public awareness increases that the problem of household waste cannot be solved only by the government, but the active role of the community is to help deal with waste problems (Gunartin, 2019). As a response to government programs, the community welcomes the presence of the waste bank program as a strategy for managing waste by moving people as customers of aampah bank. As public awareness increases that the problem of household waste cannot be solved only by the government, but the active role of the community is to help deal with waste problems (Gunartin, 2019). As a response to the government program, the community welcomes the presence of the waste bank program as a strategy for managing waste by moving people as customers of aampah bank. As public awareness increases that the problem of household waste cannot be solved only by the government, but the active role of the community is to help deal with waste problems (Gunartin, 2019). As a response to the government program, the community welcomes the presence of the waste bank program as a strategy for managing waste by moving people as customers of waste bank.

The waste bank that was started in 2011 in South Tangerang City has an important role in waste management as a form of community concern in community-based waste management. A waste bank is a container or community institution as a container for sorting and collecting waste that can be reused or recycled in order to have economic value. This is in accordance with Regulation Number 13 of 2012 concerning Guidelines for Implementing 3Rs through Waste Banks. The presence of the waste bank program is the initial step to fostering awareness of the community to care for a clean and healthy environment, starting with sorting organic or non-organic waste in the village or sub-district environment with an ideal ratio or at least one Rukun Warga and one waste bank.

South Tangerang City administratively oversees 7 (seven) districts, namely the subdistricts of Pamulang, Setu, Ciputat, East Ciputat, Serpong, North Serpong and Pondok Aren. Based on DLH 2018 data, the City of South Tangerang has 239 waste banks with a total of 8,162 waste bank customers. Of the 7 sub-districts, in the same year, the Pamulang subdistrict with the most number of waste banks was 89 waste banks with 3,507 waste bank customers. Pamulang Subdistrict has 8 (eight) sub-districts, each of which has a different number of waste banks. The achievement of establishing a waste bank at the kelurahan level in the Pamulang sub-district is presented in the figure below. 


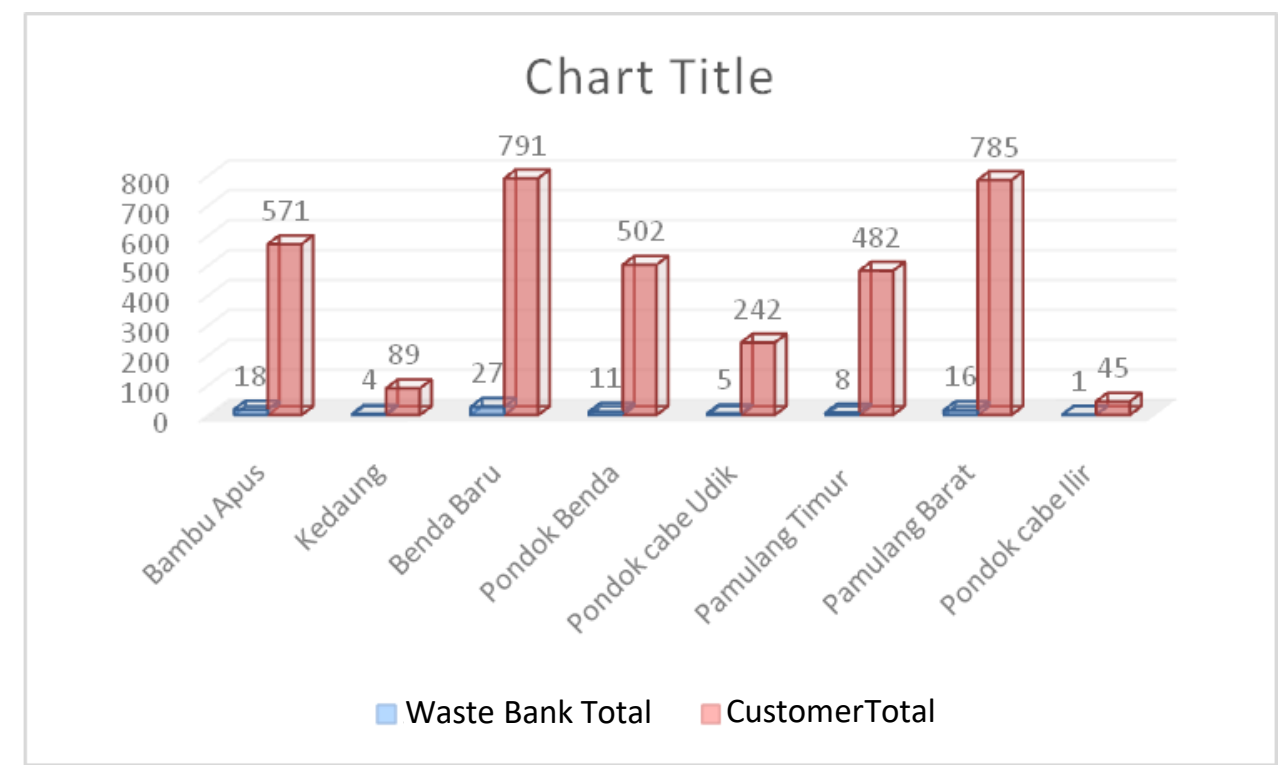

Source: Environmental Service (2018)

Figure 1. Garbage Bank and Waste Bank Customer Data

Based on the data above, the largest number of waste banks owned by Benda Baru is 27 waste banks with 791 waste bank customers. For this reason, this research is focused on the Benda Baru village, Pamulang sub-district, South Tangerang.

The waste bank system adopts the management of bank financial institutions through community empowerment. The role of the waste bank to help solve the problem of waste is guided by the implementation of reduse, reuse and recycle which is more familiar with $3 \mathrm{R}$ waste handling through the waste bank. The role of the waste bank is expected to be able to empower its customers so that they can increase their income. Even though it is not big, if it is done routinely depositing waste to the waste bank at a certain time, the results of saving waste can be enjoyed. The role of the waste bank also provides benefits to the public's perspective on cleanliness and environmental sustainability.

The presence of a waste bank is an alternative waste management solution in fostering a cultural independence of disposing of waste in its place, civilizing the community with a clean environment, opening jobs for creative mothers and getting additional income from exchanging waste for a certain amount of money. On the basis of this background, it is an encouragement for researchers to analyze the role of waste banks in an effort to improve the creative economy of society.

\section{Review of Literatures}

\subsection{The Role of the Waste Bank}

The waste bank is a social institution that is established based on the community, meaning that the awareness and concern of the community has a big role in establishing a waste bank, because it is a social work that requires training and enough time to be devoted to managing the waste bank. Therefore, usually the management of the waste bank is mothers who are not tied to activities outside the home and want to provide services to the community in a forum for social activities. A waste bank is a place to store waste that has been sorted and has economic value so that there are service activities for waste savers, according to Bambang Wintoko (2013).

A waste bank is a community institution whose work system adopts bank management of financial institutions in general, by carrying out simple bookkeeping and waste bank 
customers also getting a waste savings book to be cashed at a certain amount and time by the trash bank treasurer, as stated by Sri Suryani (2014). ). From some of these opinions, it can be concluded that a waste bank is a social institution that implements a waste deposit system that has an economic value to be saved and disbursed at a certain amount and time with a certain amount of money.

The role of waste banks in addition to contributing to reducing the volume of waste in the community and changing the value of waste also provides educational benefits for children and the community to treat waste well. Changing the perspective of waste as dirty goods becomes a source of increasing people's income, in this case the waste bank customers. The educational value for children is in addition to making a culture of throwing garbage in its place, sorting waste by type also reducing environmental pollution. And more importantly, providing education for the community, educating children to like to save, even though it is in the form of garbage.

\subsection{Community Creative Economy}

Economics can be defined as the study of the use of limited resources by individuals and communities to meet their consumption needs with various efforts to produce goods and services (Sukirno Sadono, 2016). Meanwhile, according to Manurung and Raharja (2008) economics learns about the behavior of individuals and communities in making choices to utilize resources as an effort to improve the quality of life. From these two opinions, it can be concluded that economics studies how individuals and societies use limited resources to meet their needs.

Creative economy is a concept that emphasizes the development of added value of an object through creativity and innovation to drive the economy. It is also the development of individual talents who are creative and creative based on their skills and creativity (Darwanto, 2015). The definition of creative economy according to the Ministry of Trade of the Republic of Indonesia is a small industry from developing talent through creativity and skills to create jobs for welfare. The creative industry is the government's hope for strengthening a competitive economy in the era of globalization, because in addition to contributing to GDP, it is also a sector that absorbs labor, which is a production factor for economic activity. According Gunawan (2020) the economic development of creative industries is an important aspect as a potentially good force for the national economy for the future.

\section{Research Methods}

The qualitative method is research that is intended to interpret symptoms / phenomena about the research subject (Moleong, 2011). Describing the symptoms / phenomena of the research subject in depth from the results of data collection is the approach used in this study, namely a descriptive qualitative approach. According to Sugiono (2015) qualitative research is a research method for exploring subjects in natural conditions and the researcher acts as a key instrument. As a key instrument, researchers and the team went directly to the field to dig up related information.

Research data comes from objects that have been determined in order to obtain the data needed to be able to analyze the role of the waste bank. Data sources are a very important element in research. The research data needed includes primary data, key informants, namely the coordinator of the Benda Baru Pamulang South Tangerang bank as the source. Primary data is data obtained directly from data sources in the form of verbar, verbal and the behavior of the subject (informant) which is relevant and related to the research objectives (Sugiyono, 2012). 
Secondary data which is supporting data can be in the form of document information, photos, and other notes that can be used as data sources (Sugiyono, 2012). The secondary data needed in this study are waste bank data and waste bank customer data.

\subsection{Data Collection Technique}

Data collection is a process carried out by researchers to capture problems / phenomena, information and conditions of research subjects according to the scope of research. For this purpose, a data collection strategy is needed so that the research objectives can be achieved. In this study, the research instrument was the researcher himself. Therefore, the researcher as an instrument must also be validated, namely how far the researcher carried out the research and then went down the field (Sugiyono, 2015). Therefore, data accuracy and validity are needed to determine the quality of the data obtained. with the source triangulation data collection technique. Observations are carried out openly to informants (data sources), to obtain the required data more easily and with direction.

\subsection{Data Analysis Technique}

Data analysis was carried out before, during and after field trips. According to Nasution in Sugiyono (2015), the analysis starts from the focus of research, formulating problems, before going to the field and continues until the preparation of research results. Data analysis technique is a way of describing the analysis technique used to analyze information acquisition (Sanusi Anwar, 2011). The researcher used descriptive statistical analysis technique, namely the analysis to explain the data of a variable under study, namely to describe the results of the analysis of the role of the waste bank in improving the people's creative economy.

\section{Results and Discussion}

The establishment of a waste bank is an alternative solution for waste management and fosters a culture of disposing of waste in its proper place. Waste problems that are not handled effectively can have an impact on environmental hygiene and health. In South Tangerang, the landfill for garbage disposal has already brought victims because a mountain of garbage had landslides in residential areas. Therefore, waste becomes a problem that needs serious handling because every day the volume of waste continues to increase.

Household waste is the largest contributor to waste volume, the denser the population, the greater the volume of waste every day. The existence of a waste bank actually only helps reduce the volume of waste, not one hundred percent waste-free handling, it is the community who should play an active role in dealing with waste problems. This was also conveyed by the coordinator of the Benda Baru waste bank that public awareness of waste management is an effective way of handling waste. The biggest source of waste comes from households, so it is from the household that waste management should be started so as not to cause problems.

Household waste management can be done and familiarized with the $3 \mathrm{R}$. Reducing the purchase of consumer goods is getting used to carrying shopping bags that can be used repeatedly or reducing the purchase of goods that will become waste (reduce). Another alternative, reusing used goods that can still be used (reuse) or waste (used goods) can be recycled (recycled) so as to minimize waste and have economic value. People only need to sort waste according to its type, wet waste, namely organic waste, dry waste and hazardous waste. The results of sorting waste can be deposited into a waste bank which becomes a container for collecting sorted waste. 
The Ketumbar Benda Baru waste bank is one of the waste banks that has initiated the establishment of waste banks - other waste banks in Benda Baru and its surroundings. Currently the community has begun to be interested and aware of the role of the waste bank, so many have made a comparative study to the Ketumbar waste bank to learn to manage the waste bank. The waste bank, which was established in 2013, has also experienced ups and downs, because it is not easy to make people aware of sorting their household waste. To attract people to become customers of waste banks and make it a routine to sort household waste, the Ketumbar waste bank provides door prizes in the form of basic necessities such as sugar, oil and noodles. Waste weighing is carried out once a month in the third week, also not always all waste bank customers save their waste.

The role of the waste bank cannot be maximized without the support of the local community. The classic reason for the community for not sorting it out is that there is no place to collect trash at home, there is already a garbage collector who picks up the garbage every other day. Again, if the garbage is piled up waiting to be picked up by the garbage man, the garbage cannot be separated because it becomes one between wet and dry waste, and creates an unpleasant odor because it is broken, in the end it is thrown into final disposal and becomes a waste problem. To optimize the role of the waste bank, the coordinator of the waste bank, apart from providing understanding to the community, also provides a direct example to the surrounding community by placing dry waste that has been sorted in the teras of the house. The management of the Ketumbar waste bank also did a similar thing to provide an example to the surrounding community. Every time before the weighing, the management invites the public or waste bank customers through social media groups by conceptualizing invitations as attractive as possible and providing door prizes for those who deposit waste first.

The Ketumbar waste bank plays its role in helping effectively manage waste with a network of open lapak - open stall in South Tangerang. So that the weighing of waste carried out at Balai RW 17 no longer holds dry waste, once the weighing is complete, it is immediately taken by the opening of the partner stall of the Ketumbar waste bank that has been previously communicated. That way waste deposits from customers do not need a shelter because they are taken directly by the partner stall openers. That way, apart from not needing to provide a warehouse, the waste is also immediately cashed.

The proceeds from the sale of waste to a stall starting from Rp. 500,000, - up to Rp. $2,300,000$, - showing the very high enthusiasm of the community in responding to the presence of the waste bank. This means that in addition to helping reduce the volume of waste in the community, waste banks also contribute to increasing household income even though it is not large enough. If this continues to be done in a sustainable manner and the people's response shows an upward trend, it will be able to improve the community's economy. This is also supported by previous research conducted by Arif Fadhila, et al. 2011, with the title Study of Campus Waste Management, Department of Architecture, Faculty of Engineering, Diponegoro University, with the results of research that business actors, government and academics must collaborate in a symbiotic manner in developing the creative economy by utilizing opportunities from waste.

The role of the waste bank is very potential to foster the creativity of its customers, by recycling waste into goods of high economic value, such as newspapers that are turned into pulp and printed again into flower vases, cocacola bottles that become decorative lights, plastic coffee / candy wrappers become shopping bags, thereby increasing the creative economy of society. Garbage, which in fact triggers the problem if managed is able to generate income for the community, the hope is that if creative waste bank customers are able to change the use value and economic value of waste, it will not only benefit their family's 
economic improvement but also for the wider community, with the hope that the creative economy will open up jobs for Public.

From the results of research that has been done, it shows that the waste bank has a very big role in maintaining environmental cleanliness, reducing the volume of waste and improving the community's economy even though the nominal amount given is only the amount of waste deposited by each customer. However, if the customer is patient and painstaking in collecting, sorting and saving in the form of waste deposits, the nominal received will also be large within a certain period of time. In general, the waste bank in Benda Baru Pamulang has only been carrying out its function as a waste bank where the dry waste is channeled back to the partner stall to collect garbage. Not yet until the follow-up process from waste to new recycled waste products that are competitive in the market. It has been done before, but due to constraints on human resources who have high creative power so that they are able to convert waste into goods of useful and high economic value and the problem of distribution of creative products from waste recycling is not continued. Another factor that has not optimally increased the economy from creativity in recycling waste, namelyThe public still looks down on used goods even though they have been recycled and the government's attention has not been optimal in opening distribution channels for creative waste products. So the role of the new waste bank plays a role as a container for customers and is channeled back to opening partner stalls.

\section{Conclusion}

The role of the waste bank in the Benda Baru Pamulang environment has a major contribution in handling the waste problem. Contributions that have been made to the people of South Tangerang Pamulang are in the form of reducing the volume of waste, environmental cleanliness and improving the economy of the people who are members of the waste bank customers. In general, waste banks in an effort to improve the creative economy of the community have not been implemented optimally because of process constraints caused by the lack of human resources who have creative power and the distribution of waste management products that cannot be marketed optimally.

\section{References}

Bambang Wintoko. (2013). A Practical Guide to Establishing a Waste Bank with Multiple Benefits Clean Environment and Financial Security, Cet. I, Yogyakarta: Pustaka Baru Press, h. 5760.

Darwanto Dani Danuar. (2015). Development of Small and Medium Micro Enterprises (MSMEs) Based on Creative Economy

Effendy, A., \& Sunarsi, D. (2020). Students' Perceptions of the Ability in Establishing MSMEs and the Effectiveness of Online Promotion in the City of South Tangerang. MEA Scientific Journal (Management, Economics, \& Accounting), 4 (3), 702714.https://doi.org/10.31955/mea.vol4.iss3.pp702-714

Gunartin. (2019). Analysis of the Effectiveness of Waste Banks as Alternative Waste Management in Efforts to Toward a Smart City Concept in South Tangerang City, Journal of INOVASI Vol. VI No. 1 June 2019.

Gunawan, G. et al. (2020). Determining Factors in the Use of Digital Marketing and Its Effect on Marketing Performance inthe Creative Industriesin Tasikmalaya. Budapest International Research and Critics Institute-Journal (BIRCI-Journal).P. 2543-2550 
Khoiri, A., Kahar, MS, \& Indrawati, RT. (2018). Ethnoscience Approach in Cooperative Academic Education Programs (COOP). In Journal of Physics: Conference Series (Vol. 1114, No.1).

Meleong, LJ. (2011). Qualitative Research Methodology, Bandung, PT Remaja Rosdakarya

Regulation of the Minister of Environment of the Republic of Indonesia Number 13 of 2012 concerning Guidelines for the Implementation of Reduce, Reuse and Recycle through Waste Banks, accessed on 8 May 2018, from http://jdih.mnlh.go.id> pdf> ind> INDPUU- 7-2012-Permen LH 13 th 2012 waste bank.

Sanusi Anwar. (2011). Business Research Methodology. Four Salemba. South Jakarta

Shinta, H.et al. (2020). Potential Stunting in Riverside Peoples (Study on Pahandut Urban Village, Palangka Raya City). Budapest International Research and Critics InstituteJournal (BIRCI-Journal). P. 1618-1625.

Sri Suryani. (2014). The Role of Waste Banks in Waste Management Effectiveness (Case Study of Malang Garbage Bank). Retrieved on July 16, 2017, fromhttp://jurnal.dpr.go.id> article> view

Sugiyono. (2012). Qualitative and Quantitative Research Methods R \& D. Bandung: Alfabeta.

Sugiyono. (2015). Educational Research Methods: Quantitative, Qualitative, and R \& D Approaches. Bandung: Alfabeta.

Sukirno, Sadono. (2016). Introductory Macroeconomic Theory, Third Edition. Jakarta: PT, Gramedia Pustaka Utama.

Sunarsi, D. (2019). Application of Strategic HRM in an Effort to Improve Organizational Capabilities in facing the 4.0 Revolution. MEA Scientific Journal (Management, Economics, \& Accounting), $3 \quad$ (1), 221-233. https://doi.org/10.31955/mea.vol3.iss1.pp221-233

Supriyadi, D., Syafitri ,. LNH, Widodo, SFA, Wahidi, R., Arinta ,. YN, Nabhan ,. F., Mufid ,. A., Purwanto ,. A., Fahlevi ,. M., Sunarsi ,. D. \& Cahyono ,. Y. (2020) Innovation And Authentic Leadership Of Islamic University Lectures In Faculty Pharmacy Faculty: What Is The Role Of Psychological Capital ?. Systematic Reviews in Pharmacy, 11 (8), 383-393.doi: 10.31838 / srp.2020.8.56 